\title{
Factors Affecting Uptake of Agency Banking Services Among Customers in Rural Kenya: A Case of Narok County
}

\author{
Lilian Githae \\ Dr. James Gatauwa \\ Prof. Felix Mwambia
}

Kenya Methodist University, School of Business, Nairobi, Kenya

Doi:10.19044/esj.2018.v14n16p224 URL:http://dx.doi.org/10.19044/esj.2018.v14n16p224

\begin{abstract}
The objective of this study was to analyze factors affecting uptake of agency banking services among customers in rural Kenya. Specifically, the study sought; to examine the effect of fraud on uptake of agency banking services among customers in Kenya; to determine the extent to which skills of agents affect uptake of agency banking services among customers in Kenya; To establish the effect of location on uptake of agency banking services among customers in Kenya and to find out how confidentiality affect agency banking services uptake among rural customers in Kenya. A multivariate regression model was applied to determine the relative importance of each of the four variables. The findings indicated that bank agent skills, location and confidentiality were found to be statistically significant in explaining uptake of agency banking services. Banks should create awareness to the public that the bank agent's premises adheres to standard security measures and should also hire security services from security firms to transport cash to and from the agents where necessary. Banks should also train the agency banking agents on how to detect fake money and fraud. The study revealed that agents' skills affected uptake of agency banking services by rural community in Narok County. The study recommends banks to offer training to agents before they start providing specific services on behalf of the banks to improve their customer handling skills and increase the uptake of the agency banking services.
\end{abstract}

Keywords: Agency banking, fraud, confidentiality, Kenya

\subsection{Introduction}

Agency banking refers to the provision of banking services by a third party to customers on behalf of a licensed and prudentially regulated financial 
institution such as a bank or other deposit taking institutions. In this case the agency banks is given the capacity to undertake transactions on behalf of the mother bank except that it cannot accept deposits or offer loans on its own name. Most importantly, only the owner of the agency bank or an employee of the retail outlet offers services to the clients by allowing them to pay their bills, check their account balances, transfer cash or even receive government benefits (Saat et al., 2011).

In East Africa, Kenya has made tremendous efforts towards improving access to financial services. This is because the number of people without access to financial access had reduced from 38.4\% in 2006 to $32.7 \%$ in 2012. This also attributed to the 1072 retail bank branches countywide (GOK, 2010). On the other hand the Central Bank of Kenya (CBK) has recorded over 10,000 active agents in Kenya contracted by eights banks all over the country (CBK, 2012). In 2011, in a conference held in New York one of Kenya's banks Equity Bank was credited for being outstanding in its efforts on Agency Banking in developing economies, a sign that financial access in Kenya has really taken off in the county. It is therefore not a surprise that $\mathrm{CBK}$ since the enactment of the Agency Banking Guidelines has given approval to 10 banks to run agency banking (Sara, 2015).

In Kenya, agency banking was fully embraced legally by the enactment of the Agency Banking Guidelines in 2010, by which all banks have to abide through an application to the $(\mathrm{CBK})$ in order to seek approval to conduct their transactions in any part of the country, (CBK, 2010). The enactment of guidelines by $\mathrm{CBK}$ has since promoted accessibility buy to financial services to majority of the nationals since $32 \%$ of Kenya bankable population is still accessibility to banking facilities. In 2010, the Ministry of Finance in conjunction with Kenya Bankers Association (KBA) and CBK undertook a comprehensive survey on how agency banking was done in South America focusing on Brazil and Colombia before adopting the guidelines and it was discovered that despite the benefits associated with agency banking several challenges were still likely to face with this new banking phenomenon. Issues ranging from security, fraud, customer service to bank customer to confidentially had to be addressed prompting the unveiling of Guidelines of Agent Banking (CBK, 2010). Nevertheless, the benefits were still remarkable since it enhanced remarkable savings on cost of training and also savings on the equipment needed such as furniture and computers to achieve the banking goals. CBK data shows 8,809 agency outlets were opened in 2010, most of which are being operated by Equity and Co-operative banks. KCB hopes to open about 2,500 agency branches this year, while Post bank hopes to open 500. But identifying the agents who are capable of handling cash transactions efficiently has been a challenge for the institutions, with entrepreneurs 
reporting that cash is often scarce even as rising fears of security mount at the outlets (CBK, 2010).

Currently, over 30,000 outlets around the country are enrolled as mobile money transfer agents, leaving banks with a smaller pool of businesses from which they can pick the cash-rich operations they need to roll out agency banking model. Some banks, like Co-operative, have instead opted to partner with cash-rich savings and credit cooperative organizations in order to get around this issue. The commonly cited challenges include agent costs and risks such as liquidity management, security risk, and their links with the selection criteria. There is limited empirical research on the challenges facing agency banking in rural Kenya and therefore this study seeks to highlight these challenges to enable organization seek ways of mitigating its disadvantages and aid financial institutions in decision making.

Despite the quite essence of agency banking, many banks have not embraced the model with only four banks: Equity Bank and Co-operative Bank of Kenya, Postbank and Kenya Commercial Bank (KCB) having adopted the idea by June of 2011. According to Bank Supervision Annual Report of the year 2016, Nairobi, Mombasa and Kiambu reported the highest number of transaction through agency banking whereas in Rift Valley province out of fourteen (14) counties Turkana, Uasin Gishu, Kericho, Bomet and Baringo reported higher number of transaction through bank agents compared to Narok county that made up part of the bottom four counties that comprised of Samburu, Trans-Nzoia and Elgeyo-Marakwet. While customers cite agencies' inadequate capacity to handle large transactions of cash and low security measures, banks are particularly concerned of the security involved in contracting agents and possible consumer bad experience owing that the agents are not apt at customer/public relations, thus, banks are finding it hard to convert these outlets into 'outsourced banks' (Charles, 2014, b).

According to Charles $(2014$, a) banks also are finding it hard to identify agents who are capable of handling cash transactions efficiently. Despite the advantages brought about by agency banking and the low uptake that the model has received in Narok County, no scientific study/research has been done to assess the factors affecting uptake of agency banking among rural customers in Kenya. It is against this background that this study embarks to assess the factors affecting uptake of agency banking among rural customers in Kenya with special focus on Narok County. This paper is divided into the following sections; introduction, literature review, research methodology, data analysis and conclusions and recommendations. 


\subsection{Literature Review}

\subsection{Fraud and Agency Banking}

Issues of fraud tend to hamper the progress of agency banking since most agency staff are a target of fraudsters as in most cases they are not able to easily identify fraudulent transactions such as identification forged or original cheques. According to Saat et al. (2011) security is a fundamental and increasingly important issue in today's banking industry. Over the last few years, the number of fraudulent transactions committed by third parties has risen tremendously. Consequently, fraud prevention has become a central concern to banks, customers, and public policy makers. As banking fraud might ultimately affect customer relationship quality and customer loyalty, fraud prevention and its effective communication is an important topic for academic research. This is because banking fraud hurts both banks and their customers. Banks incur substantial operating costs by refunding customers' monetary losses, while bank customers experience considerable time and emotional losses. They have to detect the fraudulent transactions, communicate them to their bank, initiate the blocking and re-issuance or reopening of a card or account, and dispute the reimbursement of their monetary losses (Sara, 2015). Becoming a fraud victim may also impact customers' perception of feeling secure and protected at their bank. Accordingly, fraud may damage the bank-customer relationship because of shattered trust and confidence as well as increased dissatisfaction because of a perceived service failure. This, in turn, may negatively affect customer loyalty and stimulate switching behavior, thereby posing a great challenge to banks by hurting the banks' reputation and impeding the attraction of new customers (Mohamed \& Tarek, 2013).

In recent decades the definition of perceived risk has changed as people have engaged in online transactions. Initially perceived risk was primarily related to fraud or product quality, but today perceived risk is related to financial, psychological, physical, or social risks in online transactions. Oonagh (2016) note that the diffusion of innovation usually takes longer the more risk adverse the innovation is. The prior research on mobile banking and other banking technologies has identified different types of risks. Firstly, there appear to be privacy and security concerns regarding mobile banking among some consumers (Oonagh, 2016). A portable list of PIN codes may also pose security threats as the list may be lost. For instance, Poon (2008) as cited in Rachdi and Ben (2011) report that some bank customers fear that the hackers may get access to their bank account via personal identification numbers (PIN).

Fraud prevention may thus entail chances for banks to enhance the relationships with their customers. It gives banks the opportunity to (re-)assure customer trust in their services. Indeed, the associated feeling of security may 
be an effective means to retain existing customers and attract new ones. However, in order to translate fraud prevention into higher-quality relationships, communication is vital. Effective communication allows a bank to evoke a shared understanding of values between itself and its customers. Banks should therefore demonstrate their knowledge and competence regarding fraud prevention by communicating anti-fraud measures effectively, thereby creating a feeling of safety among customers. This feeling of safety likely improves customer relationship quality and customer loyalty, which are key success factors in the highly competitive retail banking industry (Järvinen, 2014).

\subsection{Limited Skills and Agency Banking}

Individual factors greatly affect the performance of any business. Specific entrepreneurial characteristics have been linked entrepreneurial performance. Many researchers have established that requisite managerial skills translate into business performance, growth, and development. Specific individual skills such as achievement, motivation, knowledge, skills, and locus of control determine one's suitability to run a business (Mohammed et al., 2010 cited in Matoossi \& Grassa, 2014). Most organizations use education as an indicator of a person's skill levels or productivity. They frequently employ it as a prerequisite in hiring decisions. Human capital theory suggests that the abilities and knowledge acquired by individuals are likely to be rewarded with higher earnings in the labor market and, that education and work experience is positively related to job performance. Education and professional development programs have a positive impact on ability, knowledge, and work values; and by extension task performance. These attributes have been linked to the overall performance of a business (Mohamed \& Tarek, 2013).

Acquisition of requisite skills through education and professional development increases the ability of managers to perform because it positively affects cognitive ability. People with higher business intelligence have the ability of processing information more quickly and accurately than others. Further, these individuals also have the ability of absorbing new information and developing innovative ideas when compared to those without the professional knowledge necessary for running a business (Mizruchi et al., 2011).

A well trained and alert teller is normally the first line of defense against fraud attacks and a lot of fraud is frustrated at this level (Pauline et al., 2017). The challenge in this case is how the banks will ensure that agent employees are brought to the same standard. In agent banking in Kenya, the principal requirement of agents is to adhere to a set of minimum requirements. This means that the professional cadre of the agents is not vetted by the banking institutions even though there is a relationship between professional 
development and business performance. It follows that in most cases, the operations of some agents may not represent the corporate face of the financial institution, and neither do some have the capacity and ability to employ technology to make their businesses even more efficient and profitable. Lehman (2010) argues that because of this characteristic feature of the poor and unbanked, the agents should be well trained, trusted by customers, strategically and conveniently located, and given incentives properly to follow procedures if the promise of extending financial services to the worlds unbanked is to bear fruit.

\subsection{Location and Agency Banking}

A strategic location has a direct effect on the performance of businesses. This is because it ensures nearness and access to raw material, accessibility to business premises, good road network, busyness of the area of the business etc. Location is the choice mode of entering business and viewed location in terms of type which could be local or international location. Also, location is choice of where a business is to be located, be it small, medium and large cities or urban or rural locations (Habbash, Salama \& Dixon, 2010). Location is an indispensible factor that shapes and determines the success or failure of entrepreneurial development and business activities. It determines the effectiveness of the entrepreneurial and business activities. Previous studies have revealed that firm performance is direct influenced by individual determinants, external factors and firm characteristics (Hansen, 2012).

Kaur et al. (2010) has reported that the strategic location of the domestic firms has assisted them in achieve a positive performance. It can be argued here that location has provided domestic firms with strong force to prosper and succeed in their business. They equally noted that location has helped the firms in the area of sustainability and also imply performance. Accordingly, Berger and Black (2011) have provided evidence on the effect of location on emergence of entrepreneurs and consequently their performance. The study reported that location plays vital role in entrepreneurship development. From the ongoing, one could see that the location is vital factor of entrepreneurship development that when aligned with other entrepreneurial factor like individual determinant, external factor and firm characteristics could highly affect the entrepreneurship development and firm performance. Hence the location of an agent has been seen to critically affect agency banking. Bedman (2013) cites that the major reason for the high proportion of the unbanked is the lack of proximity between the banks and the banked. In cases where formal banking services cannot be accessed by the poor, people may resort to informal options as the most favorable alternative, irrespective of the fact that this would be more risky than actually having a conventional bank account. 


\subsection{Confidentiality and Agency Banking}

Confidentiality refers to the protection given to person's information from disclosure to unauthorized. This principle relates to not revealing information about a client to a third party without the consent of the client or clear legal approval. In agency banking, information has value and therefore bank statements, personal information, credit card numbers, trade secrets or even government documents that are dealt with in one way or another by these bank agents ought to be confidential. According to Nyarumba (2011) it is important to appreciate that the confidential banker-customer relationship contains aspect of agency which if not dealt with appropriately affect the confidential banker-customer relationship for instance the obligation of secrecy and loyalty is imposed upon an agent towards his principal. Confidentiality therefore becomes a challenge in agency banking if this relationship is betrayed which common in rural areas since security is not is guaranteed.

Furthermore, low encryption levels further compromises confidentiality in agency banking. This refers to the ability to ensure that only the client alone can read his or her financial statements. In rural banking practices, encryption levels are very low and this makes the client vulnerable since protocol tools such as SSL or TLS for communication over the internet to ensure security are not there. In addition there is a lot compromise with enforcing file permission and access control list to restrict access to sensitive banking information (Hansen, 2012). There are regions in this country, specifically the rural areas that would have only one credible outlet or existing dealer who may be used as an agent by banks. This means that several banks may share an agent and the challenge would be in relation to customer information confidentiality between banks. In such instances, banks lack processes to ensure one bank's documents or instructions do not end up with another bank, hence the lack of confidentiality when it comes to customer information in agency arrangement in rural areas (Mohamed et al., 2010). 


\subsection{Conceptual Framework}

Independent variables

Dependent variable

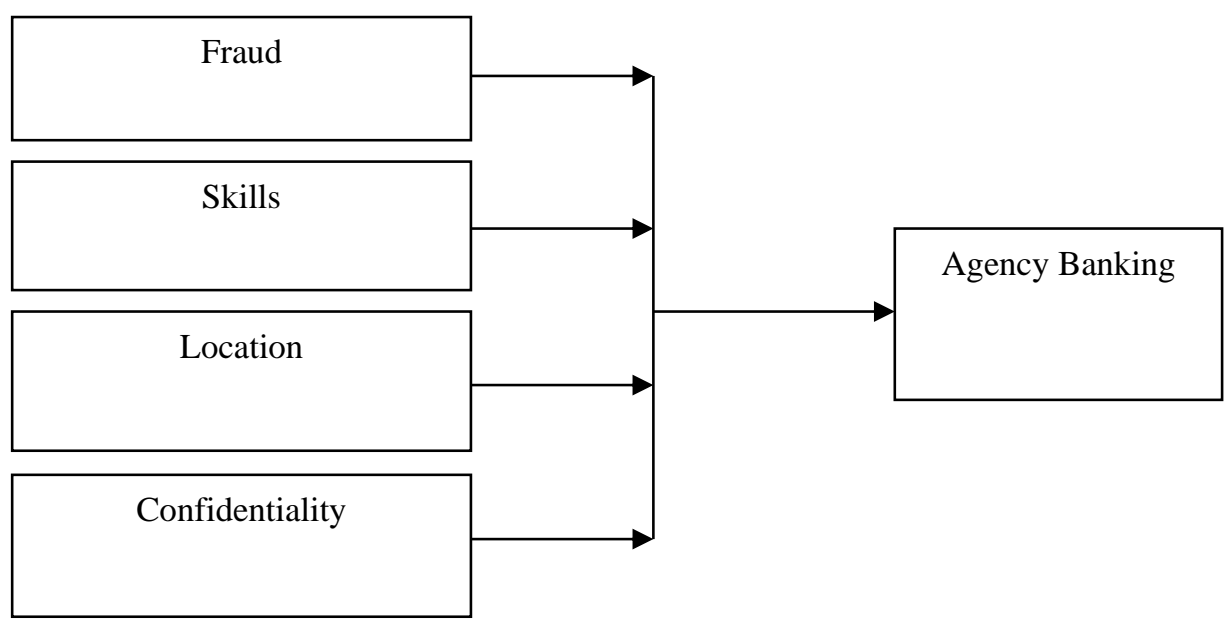

Source: Authors (2018)

Figure 1: Conceptual Framework

The study sought to establish the effect of fraud on uptake of agency banking. Issues of fraud tend to hamper the progress of agency banking since most agency staffs are a target of fraudsters as in most cases they are not able to easily identify fraudulent transactions such as identification forged or original cheques. Also the study sought the effect of bank agents 'skills on uptake of agency banking. Bank agents should be well trained, trusted by customers, strategically and conveniently located, and given incentives properly to follow procedures if the promise of extending financial services to the worlds unbanked is to bear fruit. Further, the study sought to establish the effect of location on uptake of agency banking services, a strategic location has a direct effect on the performance of businesses. This is because it ensures nearness and accessibility to business premises. Lastly, the effect of confidentially on uptake of banking agency services was sought; confidentiality refers to the protection given to person's information from disclosure to unauthorized. This principle relates to not revealing information about a client to a third party without the consent of the client or clear legal approval. In agency banking, information has value and therefore bank statements, personal information, credit card numbers, trade secrets or even government documents that are dealt with in one way or another by these bank agents ought to be confidential. 


\subsection{Research Methodology}

\subsection{Research Design}

Research design refers to the plans laid by a researcher to ensure exhaustive achievement of the research objectives (Mugenda \& Mugenda, 2008). This study adopted a descriptive analytical research design. This is a scientific method that involves observing and describing the behavior of a subject without influencing it in any way. It is designed to get more information about variables within a particular field of study. Its purpose is to provide a clear picture of a situation as it naturally happens. As a descriptive research this study aimed to provide a clear undistorted description of how the independent variables influenced the dependent variable.

\subsection{Target Population}

This refers to the members of a real or hypothetical set of people to which the researcher wishes to generate the results of the research. The targeted population comprised of approximately 14 bank branch managers, 81 bank agents and 12,000 customers from four Cooperative Bank of Kenya, Kenya commercial Bank, Post bank and Equity Bank in Narok County, Kenya. The population excluded customers in Narok town. The study utilized the formula as indicated in Krejcie and Morgan (1970).

$\mathrm{S}=\mathrm{X}^{2} \mathrm{NP}(1-\mathrm{P}) \div \mathrm{d}^{2}(\mathrm{~N}-1)+\mathrm{X}^{2} \mathrm{P}(1-\mathrm{P})$

$\mathrm{S}=$ required sample size

$\mathrm{X}^{2}=$ the table value of chi-square for 1 degree of freedom at the desired confidence level (3.841)

$N=$ the population size.

$P=$ the population proportion (assumed to be .50 since this would provide the maximum sample size).

$d=$ the degree of accuracy expressed as a proportion (0.05).

$\mathrm{S}=\mathrm{X}^{2} \mathrm{NP}(1-\mathrm{P}) \div \mathrm{d}^{2}(\mathrm{~N}-1)+\mathrm{X}^{2} \mathrm{P}(1-\mathrm{P})$

$\mathrm{S}=3.841 * 12000 * 0.5(1-0.5) \div 0.05^{2} *(12000-1)+3.841 * 0.5(1-0.5)$

$\mathrm{S}=3.841 * 12000 * 0.25 / 0.05^{2 *} * 11999+3.841 * 0.25$

$\mathrm{S}=371$

Out of population of 12000 a sample size of 371 was arrived at, the study employed stratified sampling procedure for the selection of the sample size for every category as shown in Table 1 . From every category in Table 1, a sample size equivalent to $0.031 \%$ was determined. The advantage of using this method is that it minimizes errors that occur during sampling therefore increasing the accuracy (Yin, 2009). Further, the study used census method and allowed all the branch manages and bank agents to participate in the study. The study sample size therefore comprised of 371 customers from the rural community, 81 bank agents and 14 branch managers in Narok County. 
Table 1: Sample Size

\begin{tabular}{cccc}
\hline Departments & $\begin{array}{c}\text { No. of } \\
\text { customers }\end{array}$ & Ratio(371/12000) & $\begin{array}{c}\text { Sample } \\
\text { Size }\end{array}$ \\
\hline Equity Bank ltd & 4511 & 0.031 & 139 \\
Post Bank Ltd & 1521 & 0.031 & 47 \\
Kenya Commercial Bank Ltd & 3290 & 0.031 & 102 \\
Co-Operative Bank of Kenya & 2678 & 0.031 & 83 \\
Ltd & & & $\mathbf{3 7 1}$ \\
Total & $\mathbf{1 2 0 0 0}$ & & \\
\hline
\end{tabular}

Source: Authors Computations (2018)

\subsection{Data Collection}

Questionnaires were used in this study since they gather data over a large and diverse sample. The use of questionnaires upholds confidentiality because the respondents are not required to indicate their names on it. According to Oonagh (2016) a questionnaire is an instrument with open or closed ended questions or statements to which a respondent respond. Questionnaires were administered to customers, bank agents and bank managers.

\subsection{Data Analysis and Model Specification}

Data analysis involved both qualitative and quantitative techniques. Quantitative data analysis was used to analyze quantitative data. The process began with cleaning and editing the data in the questionnaires every day after the fieldwork. This ensured that all information was captured and coded as required. After the field work, some open ended questions were coded depending on similar responses. This was followed by data entry in Statistical Packages for Social Sciences (SPSS) data sets. The data once entered were cleaned to ensure accuracy.

In addition, a multivariate regression model was applied to determine the relative importance of each of the four variables. Multiple regression is a flexible method of data analysis that may be appropriate whenever quantitative variables (the dependent) is to be examined in relationship to any other factors (expressed as independent or predictor variable). Relationships may be nonlinear, independent variables may be quantitative or qualitative and one can examine the effects of a single variable or multiple variables with or without the effects of other variables taken into account (Cohen et al., 2003). The regression model was as follows:

$Y=\beta_{0}+\beta_{1} X_{1}+\beta_{2} X_{2}+\beta_{3} X_{3}+\beta_{4} X_{4}+\varepsilon$

Where:

$\mathrm{Y}=$ Agency banking in rural Kenya; $\beta_{0}=$ Constant Term; $\beta_{1}, \beta_{2}$ and $\beta_{3}=$ Beta coefficients

$\mathrm{X}_{1}=$ Fraud$; \mathrm{X}_{2}=$ Skills; $\mathrm{X}_{3}=$ Location; $\mathrm{X}_{4}=$ Confidentiality and $\varepsilon=$ Error term 


\subsection{Data Analysis}

\subsection{Response Rate}

The data was collected from the rural community and 371 questionnaires were administered, 296 were received as complete, and therefore, all of them were viable for consideration. This represented $80.0 \%$ response rate. Out of 14 interview guide only ten managers participated representing $71.4 \%$ and lastly out of 81 bank agents only 70 participated representing $86.4 \%$. The response rates were considered excellent given the recommendations by Mugenda and Mugenda (2008) a response rate of $50 \%$ is adequate for analysis and reporting, a rate of $60 \%$ is generally good while a response rate of above $70 \%$ is excellent.

\subsection{Fraud Risk}

The study sought to determine the effect of fraud in uptake of agency banking services in Kenya, the study analyzed the descriptive statistics for the variable. The respondents' level of agreement was tested using a five point Likert scale of 1-5 where 1 - strongly disagree, 2 - disagree, 3 - neutral, 4 agree and 5 - strongly agree.

\subsubsection{Customers response on Fraud Risk}

Table 2 presents customers response on fraud risk in relation to uptake of agency banking services.

Table 2: Customers response on Fraud Risk

\begin{tabular}{llcc}
\hline Code & Fraud Risk constructs & M & SD \\
\hline F1 & Incidents of fraud at banks agents in Narok County are common & 2.4 & 0.691 \\
F2 & Bank agents premises adhere to the standard security measures & 2.9 & 0.66 \\
F3 & The agents inform the bank in case there is a robbery & 3.0 & 0.98 \\
F4 & The agents are trained to detect fake money and fraud & 2.5 & 1.01 \\
F5 & $\begin{array}{l}\text { The bank hire security services from security firms to transport cash } \\
\text { to and from the agents }\end{array}$ & 2.9 & 1.36 \\
& & & \\
\hline
\end{tabular}

Source: Authors Computations (2018)

The results in Table 2 shows that majority of the respondents did not give their opinion concerning agents informing the bank in case there is a robbery $(\mathrm{M}=3.0 ; \mathrm{SD}=0.98)$, they also did not give any opinion regarding bank agents premises adherence to standard security measures $(\mathrm{M}=2.9$; SD $=0.66$ ), they did not give their opinion concerning the question whether banks hired security services from security firms to transport cash to and from the agents $(\mathrm{M}=2.9 ; \mathrm{SD}=1.36)$. Concerning the question whether incidences of fraud are common in Narok county, majority disagreed $(\mathrm{M}=2.4 ; \mathrm{SD}=0.691)$. The respondents also disagreed that the agents are trained to detect fake money and fraud $(\mathrm{M}=2.5 ; \mathrm{SD}=1.36)$. 


\subsubsection{Bank Agents response on Fraud Risk}

Table 3 presents bank agents response on fraud risk in relation to uptake of agency banking services.

Table 3: Bank Agents response on Fraud Risk

\begin{tabular}{llcc}
\hline Code & Fraud constructs & M & SD \\
\hline F1 & $\begin{array}{l}\text { Incidents of fraud at banks agents in Narok County are } \\
\text { common }\end{array}$ & 2.4 & 0.691 \\
F2 & $\begin{array}{l}\text { Bank agents premises adhere to the standard security } \\
\text { measures }\end{array}$ & 4.4 & 0.16 \\
F3 & $\begin{array}{l}\text { The agents inform the bank in case there is robbery } \\
\text { F4 }\end{array}$ & 1.5 & 0.98 \\
F5 & $\begin{array}{l}\text { The agents are trained to detect fake money and fraud } \\
\text { the bank hire security services from security firms to }\end{array}$ & 2.5 & 1.22 \\
\hline \multicolumn{2}{c}{$\mathrm{N}=70$} & 1.65 \\
\hline
\end{tabular}

Source: Authors Computations (2018)

From the findings majority of the bank agents strongly disagreed that the bank hires security services from security firms to transport cash to and from the agents $(M=1.22$; SD 1.65), the agents inform the bank in case there is robbery $(\mathrm{M}=1.5$; $\mathrm{SD}=0.98)$. The bank agents further disagreed that incidents of fraud at banks agents in Narok County are common and that they are trained to detect fake money and fraud as shown by mean values of 2.4 and 2.5 respectively.

The bank managers were asked whether fraud risk influenced uptake of agency banking services by rural community in Narok County, the managers cited that protecting client funds is priority for many financial regulators, as loss of funds can have serious consequences for customers, as well as for public confidence in financial systems. The managers cited that physical security is a common concern of regulators. In Kenya, for example, agents must deposit the cash received from clients in a bank branch no more than every other business day. This is intended to limit cash accumulation that can lead to robbery by third parties or even by the agent itself. Kenyan regulator requires every agent transaction to be made against the agent's account at the contracting bank, to reduce the risk of third- party robbery and also eliminate the risk of agents misappropriating the accumulated cash, since the cash is in fact the agent's own.

\subsubsection{Customers' Response on Skills of Agents}

The study sought to establish the influence skills of agents on uptake of agency banking, the study analyzed the descriptive statistics for the variable. The respondents' level of agreement was tested using a five point Likert scale of 1-5 where 1 - strongly disagree, 2 - disagree, 3 - neutral, 4 agree and 5 - strongly agree. 
Table 4: Customers Response on Agents skills

\begin{tabular}{llcc}
\hline Code & Agents skills Constructs & Mean & SD \\
\hline AS1 & $\begin{array}{l}\text { The agents are trained by the bank before they start providing } \\
\text { specific services on behalf of the bank } \\
\text { Ahe banks continuously provide on job training to the agents to } \\
\text { improve their customer handling skills. }\end{array}$ & 3.2 & 0.51 \\
AS3 & $\begin{array}{l}\text { The agents are highly skilled regarding customer handling skills } \\
\mathrm{N}=105\end{array}$ & 4.4 & 0.61 \\
\hline
\end{tabular}

Source: Authors Computations (2018)

From the results in Table 4, majority of the respondents agreed that the agents are highly skilled regarding customer handling skills $(\mathrm{M}=4.4 ; \mathrm{SD}=$ 0.61 ), they did not give any opinion regarding the question "agents are trained by the bank before they start providing specific services on behalf of the bank" $(\mathrm{M}=3.2 ; \mathrm{SD}=0.51)$. The respondents did not give any opinion that the banks continuously provide on job training to the agents to improve their customer handling skills $(\mathrm{M}=3.0 ; \mathrm{SD}=1.19)$.

\subsubsection{Bank Agent's response on Agents Skills}

Table 5 presents agents response on bank agents' skills in relation to uptake of agency banking services.

Table 5: Bank Agents' response on Agents skills

\begin{tabular}{llcc}
\hline Code & Agents skills Constructs & M & SD \\
\hline AS1 & $\begin{array}{l}\text { The agents are trained by the bank before they start providing specific } \\
\text { services on behalf of the bank }\end{array}$ & 3.4 & 0.11 \\
AS2 & $\begin{array}{l}\text { The banks continuously provide on job training to the agents to } \\
\text { improve their customer handling skills. }\end{array}$ & 1.4 & 1.16 \\
AS3 & I am highly skilled regarding customer handling skills & 4.1 & 0.67 \\
\hline
\end{tabular}

$$
\mathrm{N}=70
$$

Source: Authors Computations (2018)

From the results in Table 5, majority of the bank agents agreed that they were highly skilled regarding customer handling skills $(\mathrm{M}=4.1 ; \mathrm{SD}=$ 0.67), they did not give any opinion regarding the question agents are trained by the bank before they start providing specific services on behalf of the bank $(\mathrm{M}=3.4 ; \mathrm{SD}=0.11)$. Contrary to the customers response, bank agents disagreed that the banks continuously provide on job training to the them to improve their customer handling skills $(\mathrm{M}=1.4 ; \mathrm{SD}=1.16)$.

The bank managers were asked how agents skills influenced uptake of agency banking services by rural community in Narok County, the managers cited that ability to serve customers promote uptake of services. According to a manager from Equity Bank Kenya Ltd, the bank experiences challenges because the agent employees are not brought to the same standard as bank employees. In agent banking in Kenya, the principal requirement of agents is to adhere to a set of minimum requirements. This means that the professional 
cadre of the agents is not vetted by the banking institutions even though there is a relationship between professional development and business performance. It follows that in most cases, the operations of some agents may not represent the corporate face of the financial institution, and neither do some have the capacity and ability to employ technology to make their businesses even more efficient and profitable.

\subsection{Bank Agent Location}

The study sought to find out how bank agent location on uptake of agency banking services, the study analyzed the descriptive statistics for the variable. The respondents' level of agreement was tested using a five point Likert scale of 1-5 where 1 - strongly disagree, 2 - disagree, 3 - neutral, 4 agree and 5 - strongly agree.

\subsubsection{Customers' response on bank agent location}

Table 6 presents customers' response on bank agents' location in relation to uptake of agency banking services.

\section{Table 61: Customers' response on Bank agent location}

\begin{tabular}{llrr}
\hline Code & \multicolumn{1}{c}{ Bank agent location Constructs } & Mean & Std Dev \\
\hline BAL1 & Location of bank agent determine my use of agency banking services & 4.1 & 0.69 \\
BAL2 & I use the bank agents because of closeness to my business & 4.0 & 1.05 \\
BAL3 & There is only one license agent in this area & 4.1 & 0.52 \\
\hline
\end{tabular}

$$
\mathrm{N}=105
$$

Source: Authors Computations (2018)

From the findings in Table 6, majority of the respondents agreed that location of bank agent determined their use of agency banking services $(\mathrm{M}=$ 4.1; $\mathrm{SD}=0.69)$, also the respondents were in agreement with the statement that they use the bank agents because of closeness to their business $(M=4.0$; $\mathrm{SD}=1.05)$. Lastly, the respondents agreed there was only one licensed agent in their area $(\mathrm{M}=4.1 ; \mathrm{SD}=0.52)$.

\subsubsection{Bank Agents' Response on Bank Agent Location}

Table 7 presents bank agents' response on bank agents' location in relation to uptake of agency banking services.

Table 7: Bank agents' response on Bank agent location

\begin{tabular}{clcc}
\hline Code & \multicolumn{1}{c}{ Bank agent location Constructs } & M & SD \\
\hline BAL1 & $\begin{array}{l}\text { Location of bank agent determine customer use of agency banking } \\
\text { services }\end{array}$ & 4.2 & 0.38 \\
BAL2 & Customers using the bank agents have their business around & 4.1 & 0.95 \\
\hline & $\mathrm{N}=70$ & & \\
& Source: Authors Computations (2018) &
\end{tabular}


From the findings in Table 7, majority of the bank agents agreed that location of bank agent determined customers use of agency banking services $(\mathrm{M}=4.2 ; \mathrm{SD}=0.38)$, also the respondents were in agreement with the statement that they use the bank agents because of closeness to their business $(\mathrm{M}=4.0 ; \mathrm{SD}=1.05)$. Lastly, the respondents agreed there was only one licensed agent in their area $(\mathrm{M}=4.1 ; \mathrm{SD}=0.95)$.

The bank managers were asked how location of agents influenced uptake of agency banking services by rural community in Narok County, they cited that banks have been continuously distributing agency banking outlet to increase the level of financial inclusion. They further said that increasing the area covered by agents within the country has had the effect of increasing the reach of the financial services to the people through the agents thus raising the levels of financial inclusion because a certain cliché of the population would not visit the bank branches for various reasons.

\subsection{Confidentiality}

To establish the influence of confidentiality on agency banking services in Kenya, the study analyzed the descriptive statistics for the variable. The respondents' level of agreement was tested using a five point Likert scale of 1-5 where 1 - strongly disagree, 2 - disagree, 3 - neutral, 4 - agree and 5 strongly agree.

\subsubsection{Customers' response on Confidentiality}

Table 8 presents customers' response on confidentiality in relation to uptake of agency banking services.

\section{Table 8: Customers response on Confidentiality}

\begin{tabular}{llcc}
\hline Code & \multicolumn{1}{c}{ Change in Size Constructs } & Mean & $\begin{array}{c}\text { Std } \\
\text { Dev }\end{array}$ \\
\hline Con1 & $\begin{array}{l}\text { I have trust in the bank agents and have no problem providing my personal } \\
\text { financial details. }\end{array}$ & 4.0 & 0.585 \\
Con2 & I am comfortable with the agents accessing my details from the system. \\
Con3 & $\begin{array}{l}\text { I am confident the agent has adhered to set banking standards concerning } \\
\text { security measures. }\end{array}$ & 2.1 & 0.618 \\
& & 0.49 \\
\hline
\end{tabular}

$$
\mathrm{N}=105
$$

Source: Authors Computations (2018)

From the findings majority of the respondents agreed that they had trust in the bank agents and had no problem providing their personal financial details $(\mathrm{M}=4.0 ; \mathrm{SD}=0.585)$. The respondents did not give any opinion regarding the question that they were comfortable with the agents accessing their details from the system $(\mathrm{M}=3.1 ; \mathrm{SD}=0.618)$. Lastly, the respondents disagreed that they had confidence in the agent adherence to set banking standards concerning security measures $(\mathrm{M}=2.7 ; \mathrm{SD}=0.49)$. 


\subsubsection{Bank agents' response on Confidentiality}

Table 9 presents bank agents' response on confidentiality in relation to uptake of agency banking services.

Table 9: Bank agents' response on customer Confidentiality

\begin{tabular}{|c|c|c|c|}
\hline Code & Confidentiality & Mean & SD \\
\hline Con1 & $\begin{array}{l}\text { Customers have trust in the bank agents and have no problem } \\
\text { providing personal financial details. }\end{array}$ & 1.4 & 0.11 \\
\hline Con2 & $\begin{array}{l}\text { Customers are comfortable with the agents accessing their details } \\
\text { from the system. }\end{array}$ & 3.1 & 0.618 \\
\hline Con3 & $\begin{array}{l}\text { Customers are confident the agents adheres to set banking } \\
\text { standards concerning security measures. }\end{array}$ & 2.8 & 0.48 \\
\hline
\end{tabular}

From the findings majority of the bank agents were neutral that customers were comfortable with the agents accessing their details from the system $(\mathrm{M}=3.1 ; \mathrm{SD}=0.618)$, the bank agents disagreed that customers were confident the agents adhered to set banking standards concerning security measures $(\mathrm{M}=2.8, \mathrm{SD}=0.48)$.

\subsection{Uptake of Agency banking}

The study sought to investigate the respondents' opinion on uptake of agency banking services and the results on the descriptive statistics for the variable are indicated in Table 10. The respondents' level of agreement was tested using a five point Likert scale of 1-5 where 1 - strongly disagree, 2 disagree, 3 - neutral, 4 - agree and 5 - strongly agree.

Table 10: Agency banking services

\begin{tabular}{clrr}
\hline Code & \multicolumn{1}{c}{ Uptake of agency banking services Constructs } & M & SD \\
\hline UPT1 & Cash deposits and withdrawals through agents & 4.2 & 0.736 \\
UPT2 & Payment of bills & 2.6 & 1.07 \\
UPT3 & Payment of retirement and social benefits & 3.8 & 0.874 \\
UPT4 & Payment of Salaries & 2.6 & 1.08 \\
\hline
\end{tabular}

Source: Authors Computations (2018)

From the findings majority of the respondents agreed they used agency banking services for cash deposits and withdrawals through agents $(\mathrm{M}=4.2$; $\mathrm{SD}=0.736$ ), they disagreed that they used agency banking services for payment of bills $(\mathrm{M}=2.6 ; \mathrm{SD}=1.07)$, payment of retirement and social benefits $(\mathrm{M}=3.8 ; \mathrm{SD}=0.874)$ and lastly they disagreed they used the agency banking services for payment of salaries $(\mathrm{M}=2.6 ; \mathrm{SD}=1.08)$. 


\subsection{Inferential Statistical Analysis}

This section describes the inferential statistical analysis of data which includes correlation analysis, coefficient of determination, analysis of variance and multiple regression analysis.

\subsubsection{Correlation Analysis}

The study conducted a correlation analysis of the variables of the study: fraud risk, bank agents' skills, location and confidentiality and uptake of agency banking services. To quantify the strength of the relationship between the variables, the study used Karl Pearson's coefficient of correlation. A 2-tailed Pearson Correlation test was done at $99 \%$ and $95 \%$ confidence levels and the analysis presented in Table 11.

Table 11: Correlation Analysis Matrix

\begin{tabular}{|c|c|c|c|c|c|c|}
\hline & & FR & AS & BAL & Con & UPT \\
\hline FR & $\begin{array}{l}\text { Pearson Correlation } \\
\text { Sig. (2-tailed) }\end{array}$ & 1 & & & & \\
\hline AS & $\begin{array}{l}\text { Pearson Correlation } \\
\text { Sig. (2-tailed) }\end{array}$ & $\begin{array}{c}.232(*) \\
.034\end{array}$ & 1 & & & \\
\hline BAL & $\begin{array}{l}\text { Pearson Correlation } \\
\text { Sig. (2-tailed) }\end{array}$ & $\begin{array}{l}.140 \\
.217\end{array}$ & $\begin{array}{c}.574(* *) \\
.000\end{array}$ & 1 & & \\
\hline Con & $\begin{array}{l}\text { Pearson Correlation } \\
\text { Sig. (2-tailed) }\end{array}$ & $\begin{array}{l}-.076 \\
.495\end{array}$ & $\begin{array}{l}.132 \\
.234\end{array}$ & $\begin{array}{l}.518(* *) \\
.000\end{array}$ & 1 & \\
\hline UPT & $\begin{array}{l}\text { Pearson Correlation } \\
\text { Sig. (2-tailed) }\end{array}$ & $\begin{array}{l}-.060 \\
.590\end{array}$ & $\begin{array}{c}.337(* *) \\
.002\end{array}$ & $\begin{array}{c}.792(* *) \\
.000\end{array}$ & $\begin{array}{c}.608(* *) \\
.000\end{array}$ & 1 \\
\hline
\end{tabular}

Key: $\boldsymbol{F R}=$ Fraud risk; $\boldsymbol{A S}=$ Agents' skills; $\boldsymbol{B A} \boldsymbol{L}=$ Bank agent location; $\boldsymbol{C o n}=$

Confidentiality; $\boldsymbol{U P T}=$ uptake of agency banking services

The results in Table 11 indicate that there is a positive and significant relationship between agents' skills and uptake of agency banking services $(\mathrm{r}=$ $0.337, p<0.05$ ), there is a positive and significant relationship between bank agent location and uptake of agency banking services $(r=0.792, p<0.05)$. Further, the results indicate that there is a negative and insignificant relationship between fraud risk and uptake of agency banking services $(\mathrm{r}=$ $0.060, p>0.05$ ). And lastly, the results indicate that there is a positive and significant relationship between confidentiality and uptake of agency banking services $(r=0.608, p>0.05)$.

\subsubsection{Regression Analysis}

The researcher conducted a multiple regression analysis so as to determine the factors affecting uptake of agency banking services by customers in rural Narok County, Kenya. The researcher applied the statistical 
package for social sciences (SPSS) to code, enter and compute the measurements of the multiple regressions for the study.

Table 12: Regression Model Summary

\begin{tabular}{lcccc}
\hline Model & R & R Square & $\begin{array}{c}\text { Adjusted R } \\
\text { Square }\end{array}$ & $\begin{array}{c}\text { Std. Error of the } \\
\text { Estimate }\end{array}$ \\
\hline 1 & $.920(\mathrm{a})$ & .847 & .841 & .42167 \\
\hline
\end{tabular}

a Predictors: (Constant), fraud, bank agents' skills, location and confidentiality

Source: Authors Computations (2018)

Coefficient of determination explains the extent to which changes in the dependent variable can be explained by the change in the independent variables or the percentage of variation in the dependent variable (Uptake of agency banking services) that is explained by all the independent variables (fraud risk, bank agents' skills, location and confidentiality).

The correlation and the coefficient of determination of the dependent variables when all independent variables are combined can also be measured and tested as in Table 12. From the findings $84.1 \%$ (adjusted $r$ square $=0.841$ ) of uptake of agency banking services is attributed to combination of the independent factors that relate to (fraud, bank agents' skills, location and confidentiality) investigated in this study. A further $15.9 \%$ of uptake of agency banking services is attributed to other factors not investigated in this study.

ANOVA is a set of statistical methods used mainly to compare the means of two or more samples and the estimates of variance are the key intermediate statistics calculated (Bedman, 2013). Analysis of variance (ANOVA) was used to test the significance of the regression analysis model. The ANOVA results indicate that the model of uptake of agency banking at $\mathrm{F}$ test $=138.178, \mathrm{P}>0.05$ was highly significant in predicting independent variables (fraud, bank agents' skills, location and confidentiality).

Table 13: ANOVA (b)

\begin{tabular}{ccccccc}
\hline Model & & Sum of Squares & df & Mean Square & F & Sig. \\
\hline 1 & Regression & 98.276 & 4 & 24.569 & 138.178 & $.000(\mathrm{a})$ \\
& Residual & 17.781 & 100 & .178 & & \\
& Total & 116.057 & 104 & & & \\
\hline
\end{tabular}

a. Predictors: (Constant), Fraud risk, bank agents' skills, location and confidentiality b. Dependent Variable: Uptake of agency banking services

Source: Authors Computations (2018)

\subsubsection{Coefficient of Determination}

The study conducted a multiple regression analysis and from the regression model, holding (fraud, bank agents' skills, location and confidentiality) constant at zero, uptake of agency banking was 2.003. A one percent $(1 \%)$ change in location will lead to $1.756 \%$ variation in uptake of agency banking. This result means that locating bank agents near customers has a positive impact on uptake of agency banking. 
A one percent (1\%) change in likelihood of fraud will lead to $2.057 \%$ variation in uptake of agency banking. A one percent $(1 \%)$ change in customers' confidentiality will lead to $0.635 \%$ variation in uptake of agency banking. These findings imply that customers' level of confidence determines their willingness to use bank agents. Lastly a one percent (1\%) change in bank agents' skills will lead to $0.515 \%$ variation in uptake of agency banking. This shows that there is a positive relationship between (fraud, bank agents' skills, location and confidentiality) and uptake of agency banking.

The Unstandardized beta coefficients column in Table 14 were used to obtain the overall equation as suggested in the conceptual framework. When these beta coefficients are substituted in the equation, the model becomes:

$Y=2.003+0.635 X_{1}-2.057 X_{2}+1.756 X_{3}+0.515 X_{4}$

Where;

$\mathbf{Y}=$ Uptake of agency banking, $\mathrm{X}_{1}=$ Confidentiality, $\mathrm{X}_{2}=$ Fraud, $\mathrm{X}_{3}$ $=$ Location, $\mathrm{X}_{4}=$ bank agents' skills.

Table 14: Regression Analysis Results

\begin{tabular}{|c|c|c|c|c|c|}
\hline & \multicolumn{2}{|c|}{$\begin{array}{l}\text { Unstandardized } \\
\text { Coefficients }\end{array}$} & \multirow{2}{*}{$\begin{array}{c}\text { Standardized } \\
\text { Coefficients } \\
\text { Beta }\end{array}$} & \multirow[t]{2}{*}{$\mathbf{t}$} & \multirow[t]{2}{*}{ Sig. } \\
\hline & B & $\begin{array}{l}\text { Std. } \\
\text { Error }\end{array}$ & & & \\
\hline (Constant) & 2.003 & 0.315 & & 6.356 & 0.000 \\
\hline Confidentiality & 0.635 & 0.129 & 0.586 & 4.907 & 0.000 \\
\hline Fraud likelihood & -2.057 & 0.762 & -2.1 & -2.698 & 0.008 \\
\hline Location & 1.756 & 0.763 & 1.793 & 2.302 & 0.024 \\
\hline Bank agents skill & 0.515 & 0.127 & 0.512 & 4.049 & 0.000 \\
\hline
\end{tabular}

Source: Authors Computations (2018)

\subsection{Conclusion and Recommendations}

This paper concludes that fraud likelihood affects uptake of agency banking services by rural community in Narok County. There exists a negative relationship between likelihood of fraud and uptake of agency banking services. Agents' skills affects uptake of agency banking services by rural community in Narok County. There exists a positive relationship between agents' skills and uptake of agency banking services. From the results, the agents are highly skilled regarding customer handling matters. Location affects uptake of agency banking services by rural community in Narok County. There exists a positive relationship between bank agent premises location and uptake of agency banking services. And lastly, confidentiality affected uptake of agency banking services by rural community in Narok County. The findings further reveal that there exists a positive relationship between confidentiality and uptake of agency banking services.

The study recommends that banks should create more awareness to the public that the bank agents' premises adheres to standard security measures 
and should also hire security services from security firms to transport cash to and from the agents where necessary. Banks should also train the agency banking agents on how to detect fake money and fraud. Banks should offer training to agents before they start providing specific services on behalf of the banks to improve their customer handling skills and increase the uptake of the agency banking services and they should increase the number of agents to increase the uptake of agency banking services. Confidentiality level has a significant effect on the usage of agency banking services. Thus, users with high level of confidence in the service will more readily build initial trust in agency banking. To promote confidence in the technologies, financial education must emphasize that agency banking can be cheaper, safer, and more convenient than traditional banking. The importance of privacy must also be sufficiently explained and emphasized.

\section{References:}

1. Bedman, N. (2013). SME bank selection and patronage behavior in the Ghanaian banking industry. Management Research Review, 36(11), 1061-1080.

2. Berger, A., \& Black, L. K. (2011). Bank size, lending technologies and small business finance. Journal of Banking \& Finance, 35(3), 724-735.

3. Central Bank of Kenya (2010). Guidelines on Agency Banking. CBK: Nairobi.

4. Central Bank of Kenya (2012). Annual Report. CBK: Nairobi.

5. Charles, D. (2014). Agricultural credit rationing in Kenya: what do formal lenders look for? Agricultural Finance Review, 74(3), 364-378.

6. Charles, D. (2014). Bank size, lending paradigms, and usage of farm service agency's guaranteed loan programs. Agricultural Finance Review, 74(1), 133-152.

7. Cohen, J., Cohen, P., West, S.G., \& Aiken, L.S. (2003). Applied multiple regression/correlation analysis for the behavioral sciences. $3^{\text {rd }}$ Ed. Lawrence Erlbaum Associates Publishers.

8. Government of Kenya. (2010). Economic Survey. GOK: Kenya.

9. Habbash, M., Salama, A., \& Dixon, R. (2010). The effects of nonexecutive directors' commitment and chairman independence on earnings management: UK evidence. Journal of Applied Accounting Research, 10(1).

10. Hansen, T. (2012). Understanding trust in financial services: The influence of financial healthiness, knowledge, and satisfaction. Journal of Service Research, 15(3), 280-295.

11. Järvinen, R. A. (2014). Consumer trust in banking relationships in Europe. International Journal of Bank Marketing, 32(6), 551-566. 
12. Kaur, G., Sharma, R. D., \& Seli, N. (2010). Internal market orientation in Indian banking: An empirical analysis. Managing Service Quality, 19(5), 595-627.

13. Krejcie, R.V. \& Morgan, D.W. (1970). Determining sample size for research activities. Educational and Psychological Measurement, 30, 607-610.

14. Lehman, J. (2010). Operational challenges of agent banking systems. Bill and Melinda Gates Foundation.

15. Matoossi, H., \& Grassa, R. (2014). Is corporate governance different for Islamic banks? International Journal of Business Governance and Ethics, 9(1), 27-51.

16. Mizruchi, M. S., Brewster, S., \& Fleischer, A. (2011). Getting a bonus: social networks, performance, and reward among commercial bankers. Organization Science, 22(1), 42-59.

17. Mohamed, H. B., \& Tarek, I. (2013). Impact of financial liberalization and foreign bank entry on Islamic banking performance. International Journal of Islamic and Middle Eastern Finance and Management, 6(1), 7-42.

18. Mohamed, H., Behery, T., \& Ibrahim, E. (2010). Stakeholdersoriented banks and bank performance: Perspectives from international business management. International Journal of Commerce and Management, 20(2), 120-150.

19. Mugenda O. M. \& Mugenda A. G. (2003). Research Methods: Quantitative and Qualitative Research. Nairobi: Acts Press.

20. Nyarumba, J. (2011). Financial Focus. Nairobi: PriceWaterhouseCoopers.

21. Oonagh, A. M. (2016). The federal housing finance agency's complaints against seventeen banks. Journal of Financial Crime, 23(1), 22-44.

22. Pauline, W. J., van Esterik-Plasmeijer, W., \& Raaij, F. (2017). Banking system trust, bank trust and bank loyalty. International Journal of Bank Marketing, 35(1), 97-111.

23. Poon, W.C. (2008). User's adoption of e-banking services: The Malaysian perspective. Journal of Business and Industrial Marketing, 23(1), 59-69.

24. Rachdi, H., \& Ben, A. (2011). Board characteristics, performance and risk taking behaviour in Tunisian banks. International Journal of Business and Management, 6(6), 88-97.

25. Saat, N. A. M., Karbhari, Y., Heravi, S., \& Nassir, A. M. (2011). Effective oversight roles of board of directors - the case of listed firms on Bursa Malaysia. World Review of Business Research, 1(1), 231245. 
26. Sara, J. (2015). The effects of reward system on bank credit losses an agent-based model. Managerial Finance, 41(9), 908-924.

27. Yin, R.K. (2009). Case study research: Design and methods. Vol. 5, Sage Publications. 